\title{
A munkanélküliségi rátát befolyásoló pro- és kontraciklikus változók vizsgálato SVAR-modellel
}

Szini Róbert,

a Budapesti Corvinus Egyetem PhD-hallgatója

E-mail: robert.szini@gmail.com
A munkagazdaságtan szakirodalma a munkanélküliség ciklikusságát jellemzően két, folyamattípusú változó eredőjére bontja fel: a munkanélküli státusba kiés beáramlási arányok változására, azaz azt vizsgálja, miként változik a munkanélkülivé válók és az állást találók aránya a teljes gazdasági ciklus során. Az említett két változó munkanélküliségre gyakorolt hatása, valamint azok kontra-, illetve prociklikussága kapcsán a szakirodalomban heves vita alakult $\mathrm{ki}$, melyet Shigeru Fujita eredményei tudtak végérvényesen lezárni. A tanulmány egyrészt a vita ismertetésén túl - Fujita előjelmegkötés melletti SVAR- (structural vector autoregressive - strukturális vektorautoregressziós) modelljének segítségével - bemutatja, hogy az annak lezárását jelentő eredmények hosszabb és relevánsabb idősorok alkalmazása esetén is fennállnak. Másrészt a magyar nyelvű szakirodalomban elsőként - a KSH (Központi Statisztikai Hivatal), illetve az NFSZ (Nemzeti Foglalkoztatási Szolgálat) adatsorainak felhasználásával - teszteli a modell megfelelőségét a hazai adatok esetében. Összeveti az egyesült államokbeli és a magyar idősorok alapján kapott eredményeket, amelyek Fujita számításait támasztják alá: a munkanélküliségi ráta változását egyaránt vezérli a beáramlási tényező kontraciklikus és a kiáramlási tényezö prociklikus volta is. Az is kimutatható, hogy a munkaerőpiacot érő sokk erösebben és hosszabban elnyúlva érintheti a magyarországi munkanélküliségi rátát az egyesült államokbelihez képest.

TÁRGYSZÓ:

Munkagazdaságtan.

SVAR-modell.

Munkanélküliség.

DOI: 10.20311/stat2018.08-09.hu0841 
A munkagazdaságtanra jellemző alapvető megközelítésmód szerint általánosan megállapítható, hogy gazdasági recesszió esetén a munkanélküliségi ráta emelkedése egyrészt az elbocsátások hatására növekvő munkanélküliek számának, másrészt a munkanélküli státusban eltöltött idő következtében megnövekedett elhelyezkedési időnek, valamint e két hatás együttesének tulajdonítható, mivel ezek egymást is képesek erősíteni. Ezt a tényt felhasználva a szakirodalom a munkanélküliség ciklikusságát jellemzően két, folyamattípusú változó eredőjére bontja fel: a munkanélküli státusba ki- és beáramlási arányok változására, azaz azt vizsgálja, miként változik a munkanélkülivé válók és az állást találók (elhelyezkedők) aránya a teljes gazdasági ciklus során. A szakirodalom ugyanakkor nem egységes abban a tekintetben, hogy a beáramlási arány aciklikusnak tekinthetö-e, valamint abban a kérdésben sem, hogy a munkanélküliségi rátát a be- és a kiáramlási arány képes-e jelentős mértékben befolyásolni. A következőkben szakirodalmi áttekintéssel világítom meg a problémát és annak okát, valamint bemutatom a legfrissebb álláspontot, melynek megfelelösége kapcsán, magyar adatokon vizsgálom a vázolt problémakört.

\section{A munkaerôpiaci ciklikusság modellezése}

A beáramlási arány ciklikusságának, illetve annak munkanélküliségi rátára gyakorolt hatásának empirikus vizsgálatával elöször Darby-Haltiwanger-Plant [1986] foglalkoztak, akik arra a kérdésre keresték a választ, hogy a kontraciklikus munkanélküliségi rátát a munkanélküli státusba be- vagy kiáramlók ciklikussága vezérli-e. Kutatási kérdésük mögött az a tény állt, hogy a korabeli makroökonómiai elméleti modellek a munkanélküliségi ráta kontraciklikusságát kizárólagosan a kiáramlási arány ciklikusságának tulajdonították, míg a beáramlási arány ${ }^{1}$ kapcsán aciklikusságot feltételeztek. Darby-Haltiwanger-Plant [1986] azt találták az Egyesült Államok munkaerőpiaci adatain végzett vizsgálatuk során, hogy a munkanélküliség ciklikussága majdnem teljes egészében a munkanélkülivé válók (beáramlási) arányának ciklikusságához köthető. Az említett empirikus eredményektől függetlenül a 2000-es évek elején jellemzően továbbra is olyan munkaeröpiaci elméleti modellek születtek, melyeket azon egyszerüsítő feltételezés mellett alakítottak ki,

\footnotetext{
${ }^{1}$ A cikk további részében a beáramlás minden esetben a munkanélküli státusba kerülőket, míg a kiáramlás a munkanélküli státusból kilépőket (állást találókat) jelöli.
} 
hogy a beáramlási arány aciklikusnak tekinthető. Az eddig említetteken is túllépve több elméleti modell kifejezetten azért született, hogy a beáramlási arány aciklikusságát megmagyarázza (Blanchard-Diamond [1990], Haefke-Reiter [2006], Rotemberg [2006]). A beáramlási arány aciklikusságát feltételező elméleti modelleket alkalmazó szerzőket leginkább Shimer [2005] és Hall [2005] cikkei és eredményei inspirálták. Shimer [2005] az Egyesült Államok 1984 és 2004 közötti munkanélküliségi statisztikáinak vizsgálatából megállapította, hogy igen szoros a kapcsolat a gazdaság aktuális állapota és a munkanélküliek elhelyezkedési valószínüsége között. Az állással rendelkezők elbocsátási valószínűsége nem mutat szoros kapcsolatot a gazdaság állapotával, azaz aciklikusnak tekinthető. Hall [2005] tanulmányában, szintén empirikus vizsgálatokra támaszkodva megerősítette Shimer [2005] eredményét, mely szerint a munkanélküliség inkább azért emelkedik a gazdasági ciklus lefelé ívelő ágán, mert egyre nehezebb munkát találni, és így nőhet az álláskeresési idő, mintsem azért, mert szokatlanul nagy létszámú elbocsátások következnének be.

Mindezek alapján világosan látható Darby-Haltiwanger-Plant [1986], valamint Shimer [2005] és Hall [2005] eredményei közötti ellentmondás: míg elöbbiek szerint a munkanélküliségi ráta ciklikusságát szinte teljes egészében a beáramlási arány vezérli, addig utóbbiak szerint a beáramlási arány aciklikusnak tekinthető, azaz semmiképp nem magyarázhatja a munkanélküliségi ráta kontraciklikusságát. A vitás kérdés egyértelmúen egyik fél javára sem dönthető el a következők miatt:

- Baker [1992] az Egyesült Államok munkanélküliségével kapcsolatos havi statisztikákat nyújtó CPS-adatokon (current population survey - rendszeres népességfelmérés) végzett elemzése alapján recesszió időszakában egyértelmüen hosszabb az álláskereséssel töltött idő, továbbá a kiáramlási arány erősen prociklikus, ${ }^{2}$ ami ellentmond Darby-Haltiwanger-Plant [1986] eredményeinek.

- Fujita-Ramey [2009] - szintén CPS-adatokon nyugvó - számítása szerint a kiáramlási arány prociklikussága mellett a beáramlási arány jelentősen kontraciklikusnak ${ }^{3}$ tekinthető, ami Shimer [2005] és Hall [2005] eredményeinek mond ellent. A beáramlási arány kontraciklikusságát a biztosítási statisztikákon végzett elemzések is alátámasztják, mely szerint gazdasági recesszió alatt az álláskeresőknek munkanélküliségi biztosításokból kifizetett összegek jelentősen emelkednek.

\footnotetext{
${ }^{2}$ A gazdasági ciklus felfelé ívelő ágán egyre csökken az álláskereséssel eltöltött idő, míg a lefelé ívelő ágán nő, ezért a gazdasági ciklus felfelé ívelő ágán a kiáramlási arány emelkedik, míg a lefelé ívelőn csökken.

${ }^{3}$ A gazdasági ciklus felfelé ívelő ágán egyre csökken az elbocsátások és így a munkanélkülivé válók száma, míg a lefelé ívelő ágon számuk emelkedik.
} 
Az előbbiekben bemutatott ellentmondás tisztázására Elsby-Michaels-Solon [2009] gyakorlatilag változtatás nélkül átvették a Shimer [2005] által alkalmazott módszertant a már említett CPS-adatokon, és hosszabb időtávon megismételték számításait. Elsby-Michaels-Solon [2009] empirikus tapasztalatuk alapján arra a következtetésre jutottak, hogy az általánosan elfogadott hipotézist, mely szerint a kiáramlási arány prociklikus és jelentősen befolyásolja a munkanélküliség ciklikusságát, nem lehet elvetni. Ugyanakkor - Shimer [2005] és Hall [2005] eredményeivel ellentétben - számításaik során azt tapasztalták, hogy a beáramlási arány erősen kontraciklikus, és ez a tényező is jelentősen befolyásolja a munkanélküliségi ráta változását. Elsby-Michaels-Solon [2009] azt hangsúlyozták, hogy nemcsak az előző két szerzőhöz, hanem Darby-Haltiwanger-Plant [1986] vizsgálatához képest is más eredményre jutottak, akik szerint a munkanélküliségi ráta változását leginkább a beáramlási arány változása vezérli, melyröl Shimer [2005] és Hall [2005] feltette, hogy acikliklikusak. Azaz Elsby-Michaels-Solon [2009] szerint a munkanélküliségi ráta változását egyaránt vezérli a beáramlási arány kontraciklikussága, valamint a kiáramlási tényező prociklikussága.

Elsby-Michaels-Solon [2009] Shimer számításaihoz képest csak minimális módosításokkal éltek, ugyanakkor jelentősen eltérő eredményeket kaptak, amelyek addig nem nyertek kellő bizonyosságot, amíg más szerzők ugyanezeket az eredményeket nem tudták megerősíteni vagy cáfolni. A későbbiekben Fujitanak [2011] az eredményeket egy SVAR-modell segítségével sikerült igazolnia, mely módszertan széles körben elfogadott munkaerópiaci elemzésekhez, ugyanakkor a korábbiakhoz képest egy teljesen új megközelítést jelentett. Tanulmányomban központi helyet tölt be a modell bemutatása, illetve az annak segítségével kapott eredmények kettős célt szolgálnak:

- reprodukálom Fujita [2011] eredményeit az egyesült államokbeli munkaeröpiacra vonatkozóan, de hosszabb időtávon, bizonyítva, hogy több évnyi új adat felhasználásával is fennállnak a vitatott összefüggések;

- a modellt az egyesült államokbeli mellett magyar munkaeröpiaci adatokra is alkalmazom, egyrészt annak vizsgálatára, hogy a kérdéses összefüggések a hazai viszonyokra vonatkozóan is teljesülnek-e, másrészt összevetem a kapott eredményeket.

Tekintettel arra, hogy az eddig említett szerzők empirikus eredményei kivétel nélkül az Egyesült Államok munkaeröpiaci adatain alapultak, fontosnak tartom más ország adatain végzett elemzések eredményeit is megemlíteni. Gomes [2012] tanulmányában az Egyesült Királyság 1993 és 2010 közötti munkaerőpiaci adatain végzett elemzésében a munkanélküliségi rátában bekövetkező változást felbontotta a be- és kiáramlási arányban bekövetkező változásokra, és empirikus eredményei alapján azt 
kapta, hogy a beáramlási arány nem aciklikus, sőt a kiáramlási arányhoz hasonló mértékben befolyásolja a munkanélküliségi rátát. Fontaine [2016] Franciaország 2003 és 2012 közötti munkaerőpiaci idősorait vizsgálta, a francia gazdaság egyensúlyi állapotát és annak hiányát is feltételezve. Gomeséhez [2012] hasonló eredményre jutott, azaz a francia munkanélküliségi ráta kontraciklikussága elsősorban a beáramlási arányhoz köthető, míg a kiáramlási arány csak másodlagos szerepet tölt be. Jung-Kuhn [2014] Németország és az Egyesült Államok 1980 és 2004 közötti munkaerőpiaci idősorait vetették össze. Az eredményeik alapján Németországban az átlagos be- és kiáramlási arány a vizsgált időtávon jelentősen kisebb volt az Egyesült Államokéhoz képest, ugyancsak Németország esetén a munkanélküliségi ráta kontraciklikussága inkább a beáramlási arány ciklikusságához köthető a kiáramlási aránnyal szemben.

A tanulmányban alkalmazott empirikus modell elméletileg többféle módon lenne bővíthető. Például Kertesi-Varga [2015] a munkanélküliség és az iskolázottsági szint lehetséges kapcsolatára hívja fel a figyelmet, és többek között szintén elemezhető lenne a monetáris sokkok hatása, amelyet a szakirodalomban például Pellényi [2012] vizsgált.

Az alkalmazott empirikus modell bővítésén túl érdekes további kutatási irányt adnak Ahn-Hamilton [2016], akik az előző szerzőkhöz képest egy teljesen új módszertan segítségével kívánták feloldani a be- és kiáramlási arány kontra-, illetve prociklikusságával kapcsolatos problémát. A szerzők egy, a szakirodalomban még nem alkalmazott dinamikus statisztikai modellel vizsgálták, hogy különböző sokkokra hogyan reagál rövid, közép- és hosszú távon a munkanélküliségi ráta, továbbá az álláskereséssel eltöltött idő növekedésének hatását elemezték a kiáramlási arányra vonatkozóan. További újításuk volt a korábbiakhoz - többek között a Fujita [2011] modelljéhez - képest, az egyének között értelmezett heterogenitás feltételezése és modellben való alkalmazása. Míg Hall [2005], Shimer [2005] és DarbyHaltiwanger-Plant [1986] azzal a feltevéssel éltek, hogy minden vizsgált egyén a munkanélküli státusba azonos be- és kilépési valószínűséggel rendelkezik, addig Ahn-Hamilton [2016] két eltérő munkavállalót különböztetett meg, akik közül az egyik magasabb valószínűséggel rendelkezik a munkanélküliségből való kilépéshez a másikhoz képest. Végső soron Ahn-Hamilton [2016] is Fujita [2011] későbbiekben bemutatott eredményére jut, egy attól merőben más, több korlátozó feltétel feloldása melletti modell segítségével. Ettől függetlenül elemzésemhez mégis Fujita [2011] modelljét alkalmazom. Ennek oka kettős: az Ahn-Hamilton-modell csak munkaanyag formájában érhető el, azaz lektorált folyóiratban még nem publikálták, továbbá az adatigénye sokkal nagyobb a Fujita-modellhez képest.

A továbbiakban a cikk 2. fejezetében részleteiben mutatom be az alkalmazott modellt, míg a 3. fejezetben a szükséges egyesült államokbeli és magyar idősorok forrásait ismertetem a modell eredményeivel együtt. 


\section{A SVAR-modell bemutatása}

Ebben a fejezetben a Fujita [2011] által alkalmazott SVAR-modellt mutatom be röviden, melyet a későbbiekben felhasználok mind az egyesült államokbeli, mind a magyar munkaerőpiaci adatokon. A SVAR-modellekben a VAR-modellhez (vektorautoregresszív) képest közgazdasági megfontolások alapján különféle korlátozásokat lehet elöírni (például a változók egyidejű vagy hosszú távú egymásra hatásai, előjelmegkötései). Az általam alkalmazott korlátozásokat a későbbiekben részletesen bemutatom az inputadatok forrásával, valamint az azokon végzett transzformációkkal együtt. A SVAR-módszertan kapcsán az érdeklődő olvasó figyelmébe Gottschalk [2001] cikkét, míg a VAR-módszertan kapcsán Enders [2014] könyvét ajánlom.

A Fujita [2011] által becsült modell alapvetően három változót tartalmaz: a be- és a kiáramlási arányt, valamint a betöltetlen állások számát. Az alkalmazott $k$-ad rendü VAR-modell a következő (redukált) formát ölti:

$$
\boldsymbol{\Phi}(L) \mathbf{Y}_{t}=\mathbf{v}_{t},
$$

ahol $\mathbf{Y}_{t} n$ endogén változó $t$-edik időpontbeli értékét tartalmazza, míg $\mathbf{v}_{t}$ egy $n \times 1$-es vektor, mely az egyes egyenletek hibatagjait tartalmazza, továbbá jelölje a kovarianciamátrixot $\Sigma=E \mathbf{v}_{t} \mathbf{v}_{t}^{\prime}$, valamint a $\Phi_{i}$ koefficienseket tartalmazó mátrixokat $\boldsymbol{\Phi}=\left[\Phi_{1}, \ldots, \Phi_{k}\right]$. Feltéve, hogy $\boldsymbol{\Phi}(L)$ invertálható, a következő alakhoz jutunk:

$$
\mathbf{Y}_{t}=\boldsymbol{\Psi}(L) \mathbf{v}_{t}
$$

Mivel a VAR-modell egy redukált forma, így a benne szerepeltetett változókat alakító strukturális sokkok identifikálása külön feladat (a későbbiekben ez az azonosítás elöjelmegkötéssel történik). Jelölje $\boldsymbol{\omega}_{t}$ a strukturális sokkok $n \times 1$-es vektorát, így a redukált forma hibatagjai és a strukturális sokkok közötti kapcsolatot a következő összefüggés teremti meg:

$$
\mathbf{v}_{t}=\mathbf{A} \omega_{t},
$$

ahol az A mátrix ${ }^{4}$ fogja tartalmazni a strukturális sokkok egyidejü hatását az endogén változókra nézve. A szerző felteszi továbbá, hogy a strukturális sokkok kölcsönösen függetlenek, és $E \boldsymbol{\omega}_{t} \boldsymbol{\omega}_{t}^{\prime}=$ I. A /3/-t a /2/-es összefüggésbe helyettesítve kapjuk, hogy

\footnotetext{
${ }^{4}$ A mátrix $i$-edik sorának $j$-edik eleme fogja megadni, hogy a j-edik sokk milyen egyidejű hatást gyakorol az $i$-edik változóra. Azaz az egyes hibatagok a strukturális sokkok lineáris kombinációjaként állnak elő.
} 


$$
\mathbf{Y}_{t}=\boldsymbol{\Psi}(L) \mathbf{A} \boldsymbol{\omega}_{t}
$$

Az eddigiek alapján tudjuk, hogy $\boldsymbol{\Psi}_{j}$ elóállítható $\Phi_{j}$ segítségével, amely viszont OLS- (ordinary least squares - legkisebb négyzetek) becsléssel származtatható, így A ismeretében $\mathbf{Y}_{t}$ is elöállítható $\boldsymbol{\omega}_{t}$ strukturális sokkok függvényében. A redukált forma hibatagjainak $\boldsymbol{\Sigma}$ variancia-kovariancia mátrixa ugyanakkor leszükíti az $\mathbf{A}$ mátrix lehetséges formáit, mivel teljesülnie kell, hogy $\mathbf{A A}^{\prime}=\boldsymbol{\Sigma}$. Uhlig [2005] alapján az A mátrix mindig felírható a következőképp: $\mathbf{A}=\mathbf{X} \Gamma^{1 / 2} \mathbf{Q}$, ahol $\mathbf{X}$ egy ortogonális mátrix, melynek oszlopai $\boldsymbol{\Sigma}$ ortonormált sajátvektorai, míg $\boldsymbol{\Gamma}$ egy diagonális mátrix $\boldsymbol{\Sigma}$ sajátértékeivel a föátlóban, továbbá $\mathbf{Q}$ egy ortogonális mátrix (például $\mathbf{Q Q}^{\prime}=\mathbf{I}$. Fujita [2011] cikkében csak egyetlen sokkra adott válaszokat (q) keresi, így számára q megtalálása a probléma a következö összefüggésben:

$$
\mathbf{a}=\mathbf{X} \Gamma^{1 / 2} \mathbf{q},
$$

ahol a az A mátrix egy oszlopa, amit Uhlig [2005] impulzusvektornak nevez, melynek egyes elemei az $n$ endogén változó egyidejü válaszát mutatja egy adott sokkra vonatkozóan. A Fujita [2011] által alkalmazott identifikációs stratégia ennek megfelelően $\Psi_{j}$ a-ra vonatkozó egyenlötlenségi megkötések bevezetését jelenti, amivel persze nem határozza meg a-t egyedileg, de kap egy tartományt a lehetséges válaszokra vonatkozóan, melyek konzisztensnek tekinthetők az elöjelmegkötésekkel.

A szimuláció során Fujita [2011] az előbbieknek megfelelően $1000(\boldsymbol{\Sigma}, \boldsymbol{\Phi})$ párt kapott, melyekhez kiszámítható az impulzusvektor és az IVF (impulzusválaszfüggvény) is az $n$ dimenziós gömb különböző egységvektorainak ${ }^{5}$ megfelelően. A szerző 1000 egységvektort értékelt ki az 1000 pár vonatkozásában, így összesen 1 millió q-t és impulzusválaszt kapott, majd az IVF-ek konzisztenciáját tesztelte elöjelmegkötéssel, és csak a megkötéseket teljesítőket tartotta meg.

A modell segítségével Fujita [2011] célja az Egyesült Államok munkaerópiacára vonatkozó munkaerő-allokáció ${ }^{6}$ vizsgálata, az előjelmegkötés közgazdasági célja a rövid távú negatív kapcsolat korlátozása volt a betöltetlen munkahely és a munkanélküliség között (Beveridge-görbe ${ }^{7}$ ), tekintettel arra, hogy jellemzően a magasabb

\footnotetext{
${ }^{5}$ Fujita [2011] $n$ darab véletlen számot generált standard normális eloszlásból, melyeket koordinátaként kezelt és a vektort normalizálta. Ez az $n$ dimenziós egységvektor egy pont a kérdéses $n$ dimenziós gömb vonatkozásában.

${ }^{6}$ A munkaerőpiac akkor van egyensúlyban, ha éppen akkora a munkaerőpiaci kereslet, mint a kínálat. A valóságban ez a jelenség igen ritka, így a munkaerőpiaci allokáció azon munkaerőmozgások összességének tekinthető, melyek segítségével a munkát kereső és kínáló egymásra talál a munkaerőpiacon, elősegítve ezáltal az egyensúlyi szint felé történő előrelépést.

${ }^{7}$ A strukturális munkanélküliség változásait tükrözi a betöltetlen munkahelyek száma és a munkanélküliségi ráta közötti összefüggés bemutatásával.
} 
munkanélküliség kevesebb betöltetlen munkahellyel jár együtt. Ahogy azt már a bevezetőben is említettem, Fujita [2011] számításai - egy teljesen más módszertan és új változók alkalmazása mellett - igazolták Elsby-Michaels-Solon [2009] azon eredményét, mely szerint a munkanélküliség alakulását jelentős mértékben befolyásolja az erősen kontraciklikus beáramlási arány. Tehát az ismertetett módszertannal, valamint a felhasznált új változók segítségével ismét sikerült cáfolni Shimer [2005] és Hall [2005] eredményeit, mely egyértelmü üzenetet jelentett azon modellek felé, melyek exogén módon aciklikusnak feltételezték a beáramlási arányt, és így egy fontos tényezőt rendszerint kihagytak, melynek eredményeképp kevésbé tudták megragadni a munkanélküliség valós dinamikáját.

Fujita [2011] az előbbiekhez képest további új eredményhez is jutott. A SVAR-modellből implikált IVF vizsgálatakor azt tapasztalta, hogy azok minden esetben „púpos” formát vesznek fel a kiáramlási arány, valamint a betöltetlen állások száma vonatkozásában. A kiáramlási arány IVF-jéből az olvasható le, hogy sokk hatására jelentős mértékủ az elmozdulás az egyensúlyi szinthez képest, továbbá a kiáramlási arány legkisebb értéke a sokk bekövetkezése után egy évvel fordul elö, valamint a visszatérés az egyensúlyi szinthez nagyjából az 5 . év végére történik meg. A betöltetlen állások kapcsán hasonló eredmény volt tapasztalható: a legkisebb értéket az első évnél vette fel a függvény, ugyanakkor az egyensúlyi szinthez már nagyjából a 4. év végére visszatért. Az említett „púpos” IVF-ek mellett más, egyértelmüen azonosítható eredményt is kapott a szerző: sokk esetén egyrészt a beáramlási arány és a bruttó beáramlók száma gyorsan emelkedik és tartósan magasan is marad az IVF-ek alapján, másrészt az állást találók száma kezdetben lassan reagál, de később emelkedő trendet mutat.

\section{Empirikus eredmények}

A következőkben bemutatom, milyen változók segítségével számszerüsítettem a Fujita [2011] által felhasznált SVAR-modellt, valamint, hogy ezen változók elöállításához az alapadatokat honnan értem el, és azokon milyen transzformációkat hajtottam végre. Ezt követően ismertetem az egyesült államokbeli és magyar munkaerőpiacra kapott eredményeimet.

\subsection{Input paraméterek egyesült államokbeli adatokkal}

Fujita [2011] alapján a SVAR-modellhez három idősorra volt szükségem: 


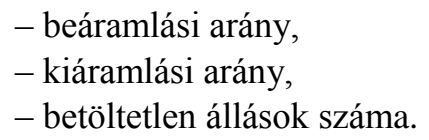

Az áramlási arányok idősorát Fujita az Egyesült Államok munkanélküliségével kapcsolatos havi statisztikákat nyújtó CPS-adatokból állította elö, és az 1976. I. és 2005. IV. negyedév közötti, szezonálisan kiigazított következő idősorokból származtatta:
a) a munkanélküli státusba beáramlók,
b) a munkanélküli státusból kiáramlók,
c) a foglalkoztatottak,
d) a munkanélküliek száma (fö).

Az adatok a BLS (Bureau of Labor Statistics - az Egyesült Államok Munkaügyi Statisztikai Hivatala) honlapján, de más időtávon érhetők el, ${ }^{8}$ mint amelyek Fujita rendelkezésére álltak. A weblapon az idősorok 1990 és 2017 között voltak elérhetők az $a$ ) és $b$ ) pontokban megjelölt változókra, míg 1948 és 2017 között a $c$ ) és $d$ ) pontokban megjelölt változókra. Az 1980-as évek végén jelentős változás történt a BLS adatgyüjtési módszertanában és az egyes küszöbértékekben, így Fujita korrekciót alkalmazott az idősorok ezutáni szakaszán. Vélhetően a be- és kiáramlók számának korábbi adatai azért nem érhetők már el a honlapon, mert a BLS csak konzisztens adatokat publikál, olyanokat, amelyek esetén az adatgyüjtés módszertanában bekövetkezett változás nem okoz törést az idősorban. Ennek megfelelöen a továbbiakban az 1990. I. és 2017. III. negyedév közötti idősorokat veszem alapul.

A be- és kiáramlási arányok az $a$ )-d) pontokban felsorolt idősorok megfelelő hányadosaiként állnak elő, ugyanakkor a hányadosképzés elött az idősorokat korrigálni kell. Erre azért van szükség, mert a havi CPS-adatok a munkanélküliség és a foglalkoztatottság tekintetében ugyan nem tartalmaznak torzítást, de a munkanélküli státusba kerülők és onnan kikerülők idősora igen. A torzítás abból fakad, hogy az egymást követő időszakokat tekintve a vizsgálat egyedeinek legfeljebb 75 százaléka esetén áll rendelkezésre az az információ, mely alapján tudható, hogy $t$-edik évről $t+1$-edik évre mely állapotba került az adott egyén (Fujita [2011] és Zellner [1985] alapján). Azaz például a foglalkoztatottból munkanélkülivé válás irányát tekintve a $t$-1-edik évben foglalkoztatottak legfeljebb 75 százalékáról tudható, hogy adott személy $t$-edik évben továbbra is foglalkoztatott vagy munkanélkülivé vált. Ugyanez igaz a $t$-1-edik évben munkanélküli státusban levőkre, így mind a beáramlási, mind a kiáramlási arányok idősora korrigálandó. Tekintettel arra, hogy véletlenszerüen hiányzik a státusváltozásról az információ és a minta kellően nagy, így a hiány nem okoz jelentős inkonziszten-

\footnotetext{
${ }^{8}$ https://www.bls.gov/webapps/legacy/cpsflowstab.htm
} 
ciát az idősorban, de a be- és kiáramlási arányok számításánál torzítást eredményezhet, melyet korrigálni szükséges. A korrekciót Fujita [2011] és Zellner [1985] alapján a következőképp végeztem el a foglalkoztatottból munkanélkülivé válók idősorán: egy adott pontját az idősornak a $t$-1-edik évben foglalkoztatottakból nyert mintán számítottam, melynek nagysága Fujita [2011] nyomán 75 százalék körüli. A konfidenciaintervallumot a következő képlet segítségével képeztem:

$$
p \pm z_{1-\alpha / 2} \sqrt{\frac{p(1-p)}{n}},
$$

ahol $p$ jelöli a 75 százalékos értéket, $n$ a foglalkoztatottak átlagos számát. A foglalkoztatottak fennmaradó 25 százaléka esetén azt feltételeztem, hogy akikröl nem tudjuk munkanélkülivé váltak-e vagy sem, azok ugyanolyan arányban válnak munkanélkülivé, mint a 75 százalékos mintában levők. Ennek megfelelően minden foglalkoztatottból munkanélkülivé váló idősorbeli elemhez a /6/ képlet alapján hozzárendeltem egy véletlen konfidenciaintervallumbeli számot, melynek a reciprokával szoroztam az idősorbeli elemeket. Ezzel a müvelettel figyelembe vettem a nem megfigyelt 25 százalékra vonatkozó információkat is. Továbbá nem egy fix értékkel skáláztam az értékeket, hanem a konfidenciaintervallumból vett véletlen érték ${ }^{9}$ segítségével, tekintettel arra, hogy a valóságban 75 százalék körül szóródik a CPS-adatokból nyerhető státusváltozással kapcsolatos információ. Ugyanezt a korrekciós módszertant alkalmaztam a másik irány esetén is, azaz a $t$-1-edik évben munkanélküli státusból $t$-edik évre foglalkoztatottá válást mutató idősornál.

A korrigált munkanélküli státusba kerülök és onnan kikerülök számosságát mutató idösorok segítéségével már kiszámíthatjuk a be- és kiáramlási arányokat a következő képletek segítségével (Fujita [2011]):

$$
\begin{aligned}
& \hat{\lambda}_{t}=\frac{e u_{t}}{e_{t-1}}, \\
& \hat{\theta}_{t}=\frac{u e_{t}}{u_{t-1}},
\end{aligned}
$$

ahol $\hat{\lambda}_{t}$ és $\hat{\theta}_{t}$ a becsült beáramlási, valamint a kiáramlási arányok, továbbá $e u_{t}$ az elözőkben létrehozott korrigált munkanélküli státusba kerülők számát a $t$-edik évben, míg $u e_{t}$ hasonlóan a korrigált munkanélküli státusból kikerülők számát jelöli, továbbá $e_{t-1}$ és $u_{t-1}$ az egy évvel késleltetett munkanélküliségi és foglalkoztatottsági értékeket reprezentálják.

\footnotetext{
${ }^{9}$ Fujita [2011] alapján ez a random-at-missing módszertan.
} 
A modellezéshez még a betöltetlen állások számának idősorára van szükségem. Fujita ezt a Conference Board által közölt ,help wanted advertising” index idősorából nyerte. ${ }^{10} \mathrm{Az}$ elemzésem során több probléma is felmerült ezzel kapcsolatban. Egyrészt Fujita [2011] 1976. I. és 2005. IV. negyedév közötti idősor adatait használta cikkében, ám jelenleg csak 2005. II. és 2017. III. negyedév közötti információk érhetők el. E változásnak az az oka, hogy az „új” idősor már az online álláshirdetések számát mutatja, míg a régi az újságokban megjelent hirdetésekét, és ezek a Conference Board oldalán már nem érhetők el. Nem az a célom, hogy Fujita [2011] számításait megismételjem, hanem az, hogy ellenőrizzem a bevezetőben említett munkaerôpiaci összefüggések teljesülését releváns idősorokon, melyek a mai munkaerőpiaci trendeket is tartalmazzák, így az adatgyüjtés módjának változása nem jelent problémát. Azaz véleményem szerint az online álláshirdetésekre építő idősor használata növeli a későbbi eredményeim relevanciáját, mivel az álláskeresés helyszíne és folyamata is jelentős mértékben átalakult az internet megjelenésével és széles körü elérhetőségével. Az újsághirdetésekben megjelent állásokra építő index relevanciája időben folyamatosan csökken.

Az adatforrásokat és a modellezéshez szükséges változók előállitási folyamatának bemutatását követően, úgy vélem számításaim eredményei relevánsabbak lesznek Fujita [2011] eredményeihez képest, tekintettel a következökre:

- a be- és kiáramlási arányok esetén „túllépek” az 1980-as évek végi jelentős adatgyüjtési problémán, így a Fujita [2011] által végzett korrekciót sem kell végrehajtanom az idősor ezt követő szakaszán;

- online álláshirdetésekre támaszkodom és nem újságokban megjelentekre, mely jobban megragadja az aktuális álláskeresési trendeket.

Számításaimat a be- és kiáramlási arányok, valamint a betöltetlen állások számának 2005. II. és 2017. III. negyedév közötti időszakára végeztem el. Az adatok minden esetben havi gyakorisággal álltak rendelkezésre, így a SVAR-modellhez szükséges negyedéves adatokat azok háromhavi átlagaként képeztem (Fujita [2011]).

Ezt követően az előállított idősorok trendjét vizsgáltam, valamint kiszürtem annak érdekében, hogy stacionárius idősorokat alkalmazhassak. Ennek megfelelően az $\mathrm{R}$ program segítségével az idősorokat felbontottam trend-, szezonális és zajkomponensekre, ${ }^{11}$ majd a trendkomponenseket kiszürtem az idősorokból. Terjedelmi korlát miatt az 1. ábrán csak az Egyesült Államok adatai alapján kapott beáramlási arány

\footnotetext{
${ }^{10}$ https://www.conference-board.org/data/helpwantedonline.cfm

${ }^{11}$ Tekintettel arra, hogy az R programban a dekompozíció többféle csomag segítségével is megvalósítható, az érdeklődő olvasó az alkalmazott programcsomagról és a módszertanról itt talál információt: https://stat.ethz.ch/R-manual/R-devel/library/stats/html/stl.html.
} 
felbontását, míg a 2. ábrán a trend szürésével kapott beáramlási arány idősorát mutatom be. ${ }^{12}$

1. ábra. Az egyesült államokbeli munkanélküliség beáramlási arányának felbontása komponensekre, 2005. II.-2017. III. negyedév

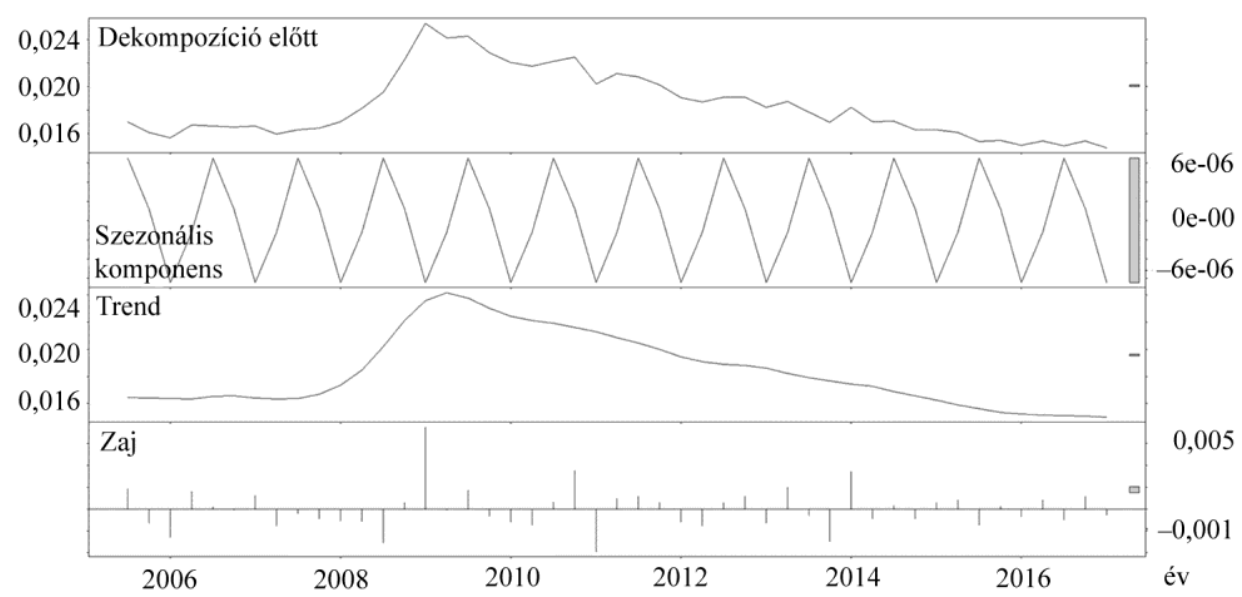

A trendkomponens kiszürésével a következö idősort kaptam a beáramlási arányra vonatkozóan, melyet a későbbiekben felhasználok.

2. ábra. Az egyesült államokbeli munkanélküliség trendszürt beáramlási aránya, 2005. II.-2017. III. negyedév

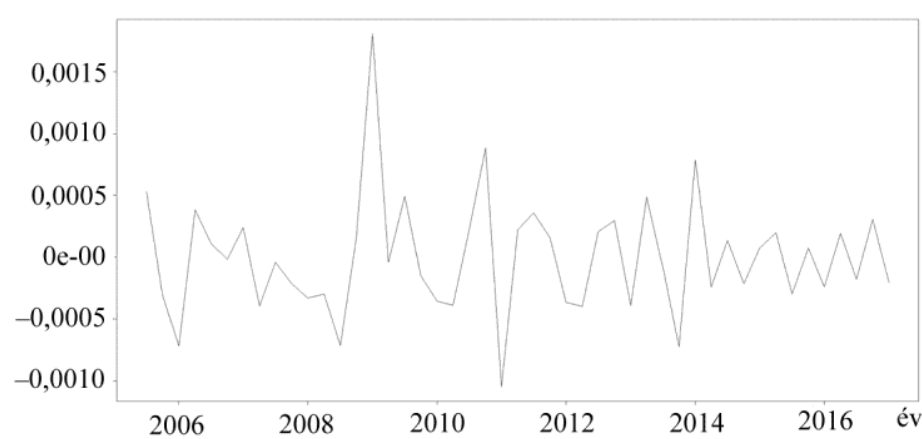

A modellezéshez szükséges továbbá a késleltetések optimális száma $(k)$, melyet az AIC (Akaike-féle információs kritérium), a HQC- (Hannan-Quinn-), valamint az SC- (Schwarz-) kritérium alapján határoztam meg (Fujita [2011]).

${ }^{12}$ A trend szürése hasonlóan történik a kiáramlási arány idősorán, valamint a betöltetlen állások idősorának logaritmusán.

Statisztikai Szemle, 96. évfolụam 8-9. szám 841-861. oldal 
Mutatószámok az optimális késleltetés kiválasztásához, az egyesült államokbeli adatok alapján

\begin{tabular}{l|c|c|c}
\hline \multirow{2}{*}{ Mutató } & \multicolumn{3}{|c}{ Késleltetés } \\
\cline { 2 - 4 } & $k=1$ & $k=2$ & $k=3$ \\
\hline \multirow{2}{*}{ AIC } & $-8,364$ & $-8,487$ & $-8,485$ \\
\hline HQC & $-8,347$ & $-8,461$ & $-8,455$ \\
\hline SC & $-8,322$ & $-8,423$ & $-8,417$ \\
\hline
\end{tabular}

Megjegyzés. Itt és a 2. táblázatban AIC (Akaike-féle információs), HQC- (Hannan-Quinn-), valamint az SC- (Schwarz-) kritérium.

Az 1. táblázatból látható, hogy az egyesült államokbeli adatok esetén mindhárom kritérium szerint $k=2$ a késleltetés optimális hossza. A három trend nélküli idősor, valamint a késleltetések optimális száma mellett, az eredmények ismertetése elött még az elöjelmegkötések definiálására van szükségünk. Mivel a becsült modellben az előjelmegkötések mindkét ország esetében ugyanazok, így azokat külön fejezetben, a magyar adatok forrásának bemutatása után tárgyalom.

\subsection{Input paraméterek magyar adatokkal}

A következőkben a 3.1. alfejezetében megjelölt, a modell számszerüsítéséhez nélkülözhetetlen három idősor (be- és kiáramlási ráták, valamint betöltetlen állások száma) magyar adatforrásait fogom bemutatni. A kérdéses három idősor előállításához szükséges adatokat a $\mathrm{KSH}^{13}$ és az NFSZ ${ }^{14}$ honlapjáról nyertem. Az NFSZ weblapján a három idősor előállításához szükséges, a 3.1. alfejezetben megjelölt öt adatsorból négyet értem el, 2000. január és 2017. október között, havi bontásban, melyek a következök:

a) regisztrált munkanélküliek száma,

b) nyilvántartásba belépők száma,

c) nyilvántartásból kilépők száma,

d) a nyilvántartásba bekerülő üres álláshelyek száma.

A hiányzó foglalkoztatottság idősort a KSH weboldaláról nyertem, negyedéves bontásban. Tekintettel arra, hogy az Egyesült Államok adatain végzett elemzésem is

\footnotetext{
${ }^{13}$ https://www.ksh.hu/docs/hun/xstadat/xstadat_hosszu/mpal2_01_02_01a.html, letöltés: 2017. december 6.

${ }^{14}$ http://nfsz.munka.hu/engine.aspx?page=stat_afsz_nyilvtartasok, letöltés: 2017 . december 6.
} 
negyedéves adatokon alapult úgy, ahogy Fujita [2011] eredményei is, így az NFSZ havi adatait szintén negyedévessé alakítottam, valamint a KSH weboldaláról nyert idősorral való összhang megteremtéséhez az időtávok szük keresztmetszetét vettem, így a számításaim és eredményeim 2000. I. és 2016. IV. negyedév közötti időtávon alapulnak. A be- és kiáramlási arányok a 3.1. alfejezetben bemutatottakkal megegyezően álltak elő, a be- és kiáramlási arányok az $a$ ) -c) pontokban megjelölt idősorok, valamint a KSH weboldaláról nyert „foglalkoztatottság” idősor hányadosai, továbbá a d) pontban megjelölt idősort használtam fel az előző fejezetben megnevezett „betöltetlen állások száma" idősorként. ${ }^{15}$ A magyar idősorokat is felbontottam trend-, szezonális és zajkomponensekre, valamint eltávolítottam a trendkomponenseket annak érdekében, hogy stacionárius idősorok álljanak rendelkezésre. A trend nélküli idősorok elóállítása mellett itt is vizsgáltam a késleltetések optimális számának $(k)$ értékét.

2. táblázat

Mutatószámok az optimális késleltetés kiválasztásához,

a magyar adatok alapján

\begin{tabular}{l|c|c|c}
\hline \multirow{2}{*}{ Mutató } & \multicolumn{3}{|c}{ Késleltetés } \\
\cline { 2 - 4 } & $k=1$ & $k=2$ & $k=3$ \\
\hline \multirow{2}{*}{ AIC } & $-4,989$ & $-5,436$ & $-5,314$ \\
\hline HQC & $-4,975$ & $-5,416$ & $-5,387$ \\
\hline SC & $-4,955$ & $-5,387$ & $-5,248$ \\
\hline
\end{tabular}

A 2. táblázatból látható, hogy a magyar idősorok mellett is $k=2$ a késleltetés optimális hossza.

\subsection{Előjelmegkötések definiálása és alkalmazása}

A következő lépést a modellezés során az elöjelmegkötések definiálása jelenti, melyet mind a magyar, mind az egyesült államokbeli idősorok esetében egyformán valósítottam meg. Fujita [2011] a következő két megkötést tette cikkében:

1. A sokk hatására a munkanélküliségben bekövetkező változás csak nemnegatív lehet legalább 2 negyedévig (azaz a munkanélküliség csak növekedhet vagy változatlan maradhat).

${ }^{15}$ Megjegyzem, hogy a magyar idősorok esetén a 3.1. alfejezetben bemutatott korrekciót nem alkalmaztam, azaz a be- és kiáramlási rátákat a /7/ és /8/ képletekből nyertem, de a számlálókban a korrigálatlan idősorok szerepeltek. 
2. A sokk hatására a betöltetlen állások száma nem emelkedhet legalább 1 negyedévig.

Az 1. megkötést a paraméterek szintjén úgy érvényesítettem a modellben, hogy a kiáramlási arány IVF-jére negatív előjelet alkalmaztam, míg a beáramlási arányra pozitívet, melyek lehetővé teszik, hogy a munkanélküliség biztosan ne csökkenjen a két negyedév alatt. A 2. megkötést pedig úgy alkalmaztam, hogy szintén negatív elöjelet rendeltem a betöltetlen állások számának logaritmusát tartalmazó IVF-hez. A kérdéses előjelmegkötések melletti szimulációt az R modellező programma $1{ }^{16}$ hajtottam végre. ${ }^{17}$

Az eredmények ismertetése előtt bemutatom, hogyan vezethetők le a be- és kiáramlási arányok IVF-jei mellett azok bruttó (stock) értékeinek IVF-jei: a háromváltozós VAR-modellböl kapott impulzusválaszok segítségével. Ehhez Fujita [2011] alapján elöregörgetéssel a következő három egyenletből álló egyenlöségrendszert kell megoldani:

$$
\begin{gathered}
l_{t}=\lambda_{t}\left[-\left(u_{t-1}-\frac{\lambda_{t}}{\lambda_{t}+p_{t}}\right) \frac{1-e^{-\left(\lambda_{t}+p_{t}\right)}}{\lambda_{t}+p_{t}}+\frac{p_{t}}{\lambda_{t}+p_{t}}\right], \\
h_{t}=p_{t}\left[\left(u_{t-1}-\frac{\lambda_{t}}{\lambda_{t}+p_{t}}\right) \frac{1-e^{-\left(\lambda_{t}+p_{t}\right)}}{\lambda_{t}+p_{t}}+\frac{\lambda_{t}}{\lambda_{t}+p_{t}}\right], \\
u_{t}-u_{t-1}=l_{t}-h_{t},
\end{gathered}
$$

ahol $l_{t}$ a $t$-edik évben a bruttó elbocsátottak, míg $h_{t}$ a $t$-edik évben a bruttó elhelyezkedők, továbbá $\lambda_{t}$ és $p_{t}$ a be- és kiáramlási arányok impulzusait jelölik, melyeket az előzők során nyertünk. Az $u_{t-1}$ a $t$-1-edik évi munkanélküliségi ráta, melyhez meg kell adni a kezdő értéket ahhoz, hogy a /9/-/11/ egyenlőségrendszert elöregörgetéssel meg tudjuk oldani. A szerző az $u_{0}$ paramétert az átlagos historikus munkanélküliségként értelmezte, azaz $\bar{\lambda} /(\bar{\lambda}+\bar{p})$, ahol $\bar{\lambda}$ és $\bar{p}$ a historikus átlagokat reprezentálják. Mindezeknek megfelelően elkészíthető $l_{t}$ és $h_{t}$ IVF-je, valamint a munkanélküliségi ráta kivetítése, hogy a sokk hatására hogyan változik annak szintje negyedévenként, a sokk pillanatától kezdődően. A levezetésnek meg-

\footnotetext{
${ }^{16}$ A modellezés során a VARsignR programcsomagot alkalmaztam, mely letölthető a következő weboldalról: https://cran.r-project.org/web/packages/VARsignR/.

${ }^{17}$ Megjegyzem, hogy az R programcsomagban csak és kizárólag időben egyféle megkötést lehet alkalmazni, azaz mindkét megkötés érvényesítése során két negyedéves hatást állítottam be, így a 2. megkötésnél eltértem Fujita egy negyedéves feltevésétől.
} 
felelően az meghatároztam az IVF-eket, ezeket részletesen a következő fejezetben tárgyalom.

\subsection{Idősoros eredmények összehasonlítása}

A következő ábrán az egyesült államokbeli és a magyar adatokon becsült SVAR-modellböl származtatott IVF-ek, valamint a hozzá tartozó konfidenciasávhatárok láthatók.

3. ábra. A SVAR-modellböl származtatott median target, IVF és konfidencia-sávhatárok negyedévek szerint az egyesült államokbeli és magyar adatok alapján

a) Kiáramlási arány
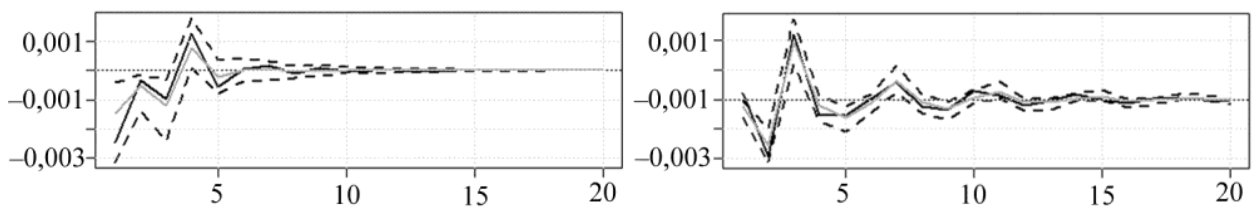

b) Beáramlási arány
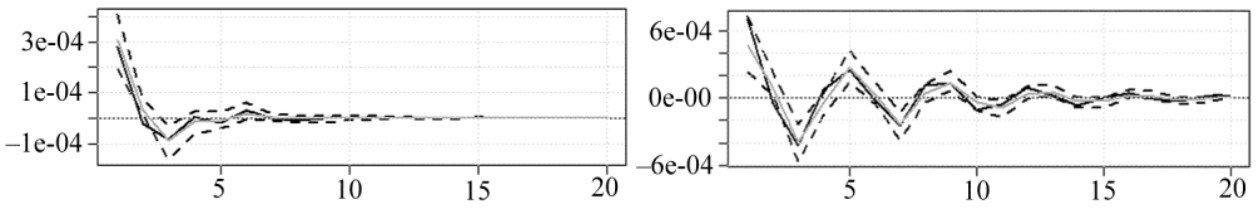

c) Betöltetlen állások
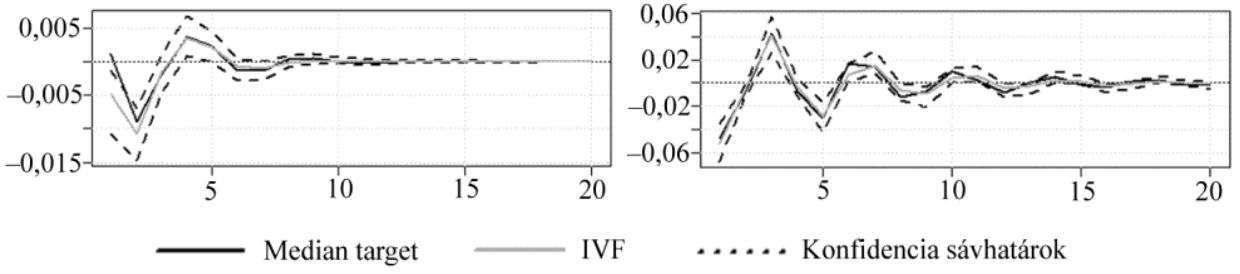

Megjegyzés. SVAR (structural vector autoregressive): strukturális vektor-autoregressziós), IVF: impulzusválasz-függvény.

A 3. ábra alapján látható, hogy az elöjelmegkötések teljesülnek a releváns IVF-ek esetén. Az egyesült államokbeli adatokon becsült SVAR-modell alapján megállapítható, hogy a kiáramlási arány IVF-je a sokk hatására a minimális értékét pont a sokk után közvetlenül veszi fel, azaz a sokk a kiáramlást eleinte nagyon 
negatívan érinti. Az egyensúlyi szintre a 4. negyedév során tér vissza az IVF, továbbá stabilizálódni csak a 6. negyedév körül fog. A magyar adatok IVF-je alapján az látható, hogy a sokk - az egyesült államokbeli esettel ellentétben - a kiáramlási arányra a 2 . negyedévig folyamatosan fejti ki negatív hatását, így nem azonnal, hanem 2 negyedév után érjük el a mélypontot. További érdekesség, hogy míg az Egyesült Államok adatai alapján a sokk hatása körülbelül a 6. negyedév végére cseng le, addig a magyar adatok esetén ez jelentősen tovább tart, azaz akár 3 évig is elhúzódhat a lecsengés.

Az Egyesült Államokat tekintve látható, hogy a beáramlási arány IVF-je a legmagasabb értékét a kezdetekkor veszi fel, azaz a sokk hatására hirtelen emelkedik meg a munkanélküliek száma, mely hatás viszonylag gyorsan lecseng, és a 3. negyedév környékén már eléri az egyensúlyi szintet, továbbá a 7. negyedévre stabilizálódik is. A magyar adatoknál ugyanaz a jelenség tapasztalható, mint a kiáramlási arány esetén: a sokk hosszabb időn keresztül fejti ki hatását, azaz akár 4 év is lehet, míg annak hatása teljesen lecseng.

A betöltetlen állások száma kapcsán megállapítható, hogy az Egyesült Államok IVF-je a sokk hatására nem az 1., hanem a 2. negyedévben veszi fel minimális értékét, azaz a sokk után még 1 negyedévig tovább csökken a betöltetlen álláshelyek száma, utána meredeken emelkedik és a 4 . negyedévre újra eléri az egyensúlyi szintet, valamint a 8. negyedévre stabilizálódik az IVF. Megjegyezem, hogy a sokk hatására csökkenő betöltetlen állások száma mögött az a tény áll, hogy egy gazdasági sokk esetén nemcsak az új álláslehetőségek száma csökken, hanem a foglalkoztatók a már meghirdetett üres státusokat is jellemzően betöltetlenül visszavonják. A magyar adatokhoz tartozó IVF alapján itt is két következtetés vonható le: a sokk hatása egyrészt az egyesült államokbeli adatokon kapott eredményekkel szemben azonnal, már a kezdetekkor élesen jelentkezik, másrészt itt is tovább tart, és 4 év után cseng le teljesen.

A 3. ábra kapcsán még nem ismertettem a folytonos fekete vonalak (FryPagan) funkcióját. Tekintettel arra, hogy az előjelmegkötés módszertanát több kritika (Fry-Pagan [2011]) érte amiatt, hogy nem egy konkrét IVF-et határoz meg, hanem egy halmazt, mégpedig különböző modellekből származó IVF-ek halmazát, így a Fry-Pagan által javasolt median target módszertan eredményét is feltüntettem az ábrán. Ezt azt jelenti, hogy a median target módszertan lehetővé teszi egyetlen impulzusvektor megtalálását, melyből a származtatott impulzusválaszok a lehető legközelebb vannak a medián impulzusválaszokhoz. Ha az eredeti és a median target módszertan segítségével kapott IVF-ek jelentősen eltérők, úgy az identifikációs problémát jelez. A 3. ábráról látható, hogy a hagyományos és a median target módszertan alapján kapott IVF-ek egyáltalán nem esnek egymástól messze, melyből az a következtetés vonható le, hogy nem áll fenn identifikációs probléma. 
A /9/-/11/ szerinti levezetések mellett számszerüsített, a magyar és egyesült államokbeli adatokon becsült modell segítségével kapott bruttó be- és kiáramlás ${ }^{18}$ IVF-jeit a 4. ábra mutatja.

4. ábra. A bruttó be-és kiáramlás IVF-jei az egyesült államokbeli és magyar adatok alapján

a) Egyesült Államok

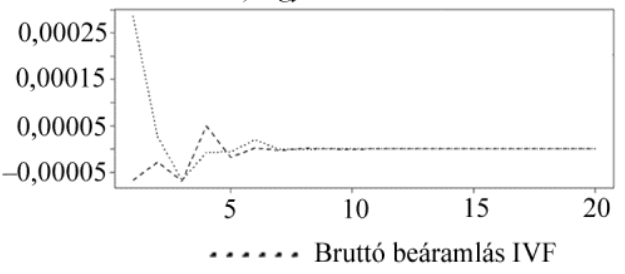

b) Magyarország

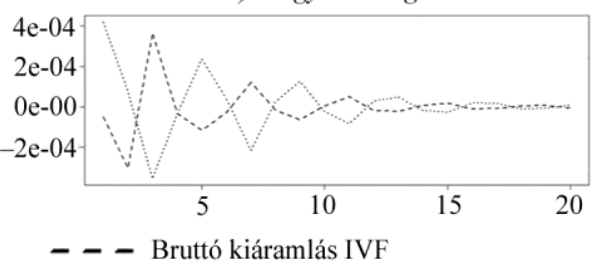

Megjegyzés. IVF: impulzusválasz-függvény.

A 4. ábrán látható, hogy az egyesült államokbeli bruttó beáramlás IFV-je a kezdetekkor sokkal jobban megemelkedik, mint amennyivel csökken a bruttó kiáramlás, továbbá a sokk hatása mindkét változót tekintve a 8 . negyedév körül cseng le. A magyar esetben a beáramlás a sokk után szintén jelentősebb mértékben emelkedik, mint ahogy a kiáramlás csökken, ugyanakkor a kiáramlás a sokk után nemhogy nem emelkedik, hanem a 3. negyedévig folyamatosan csökken, és csak utána kezd növekedni, továbbá a sokk jóval később cseng le a két változónál.

Az 5. ábrán szintén a /9/-/11/ szerint kapott munkanélküliségi ráta IVF-jét tüntettem fel.

5. ábra. A munkanélküliségi ráta IVF-je az egyesült államokbeli és magyar adatok alapján
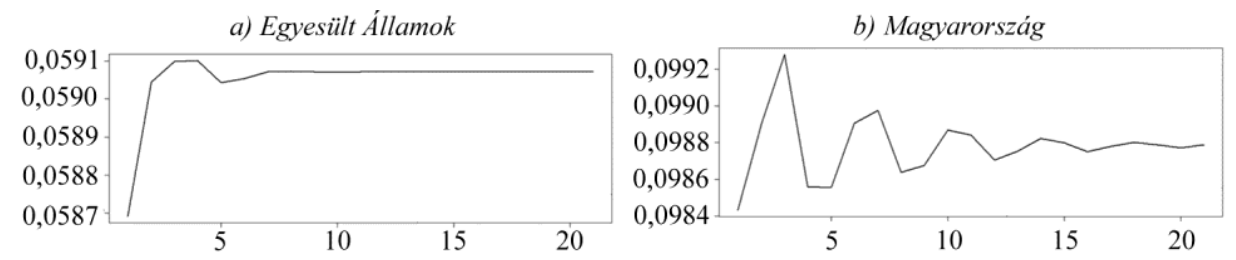

Megjegyzés. IVF: impulzusválasz-függvény.

$\mathrm{Az}$ 5. ábrán látható, hogy az egyesült államokbeli munkanélküliségi ráta IVF-jének szintje meredeken emelkedik a sokk hatására a 3. negyedévig, majd a 7. negyedévben a sokk elötti állapothoz képest magasabb szinten stabilizálódik. Ugyanez tapasztalható Magyarország esetén, azzal a különbséggel, hogy a sokk hatása sokkal később cseng le.

${ }^{18}$ Azaz itt az eddigiekkel ellentétben nem a rátára, hanem a bruttó értékre vonatkozó eredményeket közlöm. 


\section{4. Összefoglalás}

Tanulmányom célja kettős: egyrészt a munkaerőpiaci be- és kiáramlási arány kontra-, illetve prociklikusságának, valamint az azok munkanélküliségre gyakorolt hatásaival kapcsolatos elméleti vitának a bemutatása, másrészt a magyar adatokon végzett elemzés segítségével állásfoglalás a ciklikussággal kapcsolatos vitában. Igazoltam a SVAR-modell megfelelöségét a magyar munkaerőpiacra vonatkozó adatokkal is, melynek vizsgálata úttöröjellegünek tekinthető a magyar nyelvü szakirodalomban.

$\mathrm{Az}$ egyesült államokbeli és a magyar adatokon végzett empirikus vizsgálatom eredményei - melyek egybevágnak Elsby-Michaels-Solon [2009], illetve Fujita [2011] tanulmányában közöltekkel - a következök:

- sokk hatására az SVAR-modellben szerepeltetett változók (a beés kiáramlási arány, valamint a betöltetlen állások száma) mindkét ország esetén hasonlóan viselkednek;

- a be- és kiáramlási aránynak jelentős szerepe van a munkanélküliség alakulásában, sokk hatására mindkét ország esetén az tapasztalható, hogy a beáramlási arány sokkal nagyobb mértékben emelkedik, mint ahogy a kiáramlási arány csökken, azaz előbbit jobban érinti a sokk;

- a magyar változók az egyesült államokbeliekhez hasonlóan reagálnak a sokkokra, ugyanakkor azok hatásának lecsengése sokkal hosszabb időt igényel, mint az Egyesült Államokban;

- sokk hatására a kiáramlási arány az Egyesült Államok esetében jelentősen visszaesik, majd szinte azonnal emelkedni kezd, míg Magyarországot tekintve a sokk után a kiáramlási arány tovább esik és csak a 3. negyedévben éri el a minimumát.

\section{Irodalom}

Ahn, H. J. - Hamilton, J. D. [2016]: Heterogeneity and Unemployment Dynamics. National Bureau of Economic Research. Working Paper. No. 22451. Cambridge. https://doi.org /10.3386/w22451

BAKER, M. [1992]: Unemployment duration: compositional effects and cyclical variability. American Economic Review. Vol. 82. Issue 1. pp. 313-321.

BlanchaRd, O. J. - Diamond, P. [1990]: The cyclical behavior of the gross flows of US workers. Brookings Papers on Economic Activity. Vol. 2. pp. 85-143. https://doi.org/10.2307/2534505

Darby, M. R. - Haltiwanger, J. C. - Plant, M. W. [1986]: The Ins and Outs of Unemployment: The Ins Win. National Bureau of Economic Research. Working Paper. No. 1997. Cambridge. https://doi.org/10.3386/w1997 
Elsby, M. W. L. - Michaels, R. - Solon, G. [2009]: The ins and outs of cyclical unemployment. American Economic Journal: Macroeconomics. Vol. 1. No. 1. 84-110. http://dx.doi.org /10.1257/mac.1.1.84

ENDERS, W. [2014]: Applied Econometric Time Series, 4th Edition. Wiley. Hoboken.

FRY, R. - PAGAN, A. [2011]: Sign restrictions in structural vector autoregressions: a critical review. Journal of Economic Literature. Vol. 49. Issue 4. pp. 938-960. http://dx.doi.org /10.1257/jel.49.4.938

FONTAINE, I. [2016]: French unemployment dynamics: a „three-state” approach. Revue d'Économie Politique. Vol. 126. Issue 5. pp. 835-869. http://dx.doi.org/10.3917/redp.265.0835

FujITA, S. [2011]: Dynamics of worker flows and vacancies: evidence from the sign restriction approach. Journal of Applied Economics. Vol. 26. No. 1. pp. 89-121. http://dx.doi.org $/ 10.1002 /$ jae. 1111

Fujita, S. - RAmeY, G. [2009]: The cyclicality of the separation and job finding rates. International Economic Review. Vol. 50. Issue 2. pp. 415-430. http://dx.doi.org/10.1111/j.14682354.2009.00535.x

Gomes, P. [2012]: Labour market flows: facts from the United Kingdom. Labour Economics. Vol. 19. Issue 2. pp. 165-175. http://dx.doi.org/10.1016/j.labeco.2011.08.002

GotTSCHALK, J. [2001]: An Introduction Into the SVAR Methodology: Identification, Interpretation and Limitations of SVAR Models. Working Paper. No. 1072. Kiel Institute of World Economics. Kiel.

HAefke, C. - ReITER, M. [2006]: Endogenous Labor Market Participation and the Business Cycle. Institute of Labor Economics. Discussion Paper. No. 2029. Bonn. https://core.ac.uk/download /pdf/39354586.pdf

HALL, R. E. [2005]: Employment efficiency and sticky wages: evidence from flows in the labor market. Review of Economics and Statistics. Vol. 87. Issue 3. pp. 397-407. http://dx.doi.org/10.1162/0034653054638346

Jung, P. - KuHN, M. [2014]: Labour market institutions and worker flows: comparing Germany and the US. The Economic Journal. Vol. 124. Issue 581. pp. 1317-1342. http://dx.doi.org/10.1111/ecoj.12118

KeRTESI G. - VARGA J. [2005]: Foglalkoztatás és iskolázottság Magyarországon. Közgazdasági Szemle. LII. évf. Július-augusztus. 633-662. old.

PELLÉNYI G. [2012]: A monetáris politika hatása a magyar gazdaságra. Elemzés strukturális, dinamikus faktormodellel. Közgazdasági Szemle. LIX. évf. Március. 263-284. old.

Rotemberg, J. J. [2006]: Cyclical Wages in a Search-and-Bargaining Model with Large Firms. National Bureau of Economic Research. Working Paper. No. 12415. Cambridge. http://dx.doi.org/10.3386/w12415

SHIMER, R. [2005]: The cyclicality of hires, separations, and job-to-job transitions. Federal Reserve Bank of St. Louis Review. Vol. 87. Issue 4. pp. 493-507. http://dx.doi.org/10.20955/r.87.493508

UhLIG, H. [2005]: What are the effects of monetary policy on output? Results from an agnostic identification procedure. Journal of Monetary Economics. Vol. 52. Issue 2. pp. 381-419.

ZELLNER, A. J. [1985]: Estimating gross labor force flows. Journal of Business and Economic Statistics. Vol. 3. Issue 3. pp. 254-283. 


\section{Summary}

According to the labour economics literature, the cyclicality of the unemployment rate can be split into the impacts of two flow type variables, the inflow rate to unemployment from employment and the outflow rate to employment from unemployment. Thus the in- and outflow rate behaviours are examined through a whole economic cycle to describe changes in the unemployment rate. There was an intense debate among experts of labour economics about the effects of these two variables on the unemployment rate and their pro- and countercyclical behaviours, which was wound up by the results of Shigeru Fujita. This article starts with the introduction of the debate, and next uses Fujita's SVAR (structural vector autoregressive) model with a sign restriction approach to show that the results, which closed the aforementioned debate, are valid even for longer time series. For the first time in the Hungarian labour economics literature, the author checks the validity of Fujita's results on Hungarian data published by the Hungarian Central Statistical Office and the Public Employment Service. Comparison of the results based on US time series with the ones yielded by Hungarian time series underpins Fujita's findings: the unemployment rate is influenced by both countercyclical inflow rate and procyclical outflow rate. At the same time, labour market shocks can have more severe and longer lasting effects on the Hungarian unemployment rate than on the US unemployment rate. 